Article

\title{
Homogenization of Endosymbiont Communities Hosted by Equatorial Corals during the 2016 Mass Bleaching Event
}

\author{
Sudhanshi S. Jain ${ }^{1, *(\mathbb{D}}$, Lutfi Afiq-Rosli ${ }^{1,2}{ }^{,}$Bar Feldman ${ }^{3}$, Oren Levy ${ }^{3}$, Jun Wei Phua ${ }^{1}$, \\ Benjamin J. Wainwright ${ }^{4}$ and Danwei Huang $1,2, *$ (D) \\ 1 Department of Biological Sciences, National University of Singapore, 16 Science Drive 4, \\ Singapore 117558, Singapore; lutfiafiqrosli@u.nus.edu (L.A.-R.); a0078535@u.nus.edu (J.W.P.) \\ 2 Tropical Marine Science Institute, National University of Singapore, 18 Kent Ridge Road, \\ Singapore 119227, Singapore \\ 3 The Mina and Everard Goodman Faculty of Life Sciences, Bar-Ilan University, Ramat Gan 5290002, Israel; \\ barbarfel24@gmail.com (B.F.); oren.levy@biu.ac.il (O.L.) \\ 4 Yale-NUS College, National University of Singapore, 16 College Avenue West, Singapore 138527, Singapore; \\ ben.wainwright@yale-nus.edu.sg \\ * Correspondence: dbsjss@nus.edu.sg (S.S.J.); huangdanwei@nus.edu.sg (D.H.)
}

Received: 29 July 2020; Accepted: 4 September 2020; Published: 7 September 2020

\begin{abstract}
Thermal stress drives the bleaching of reef corals, during which the endosymbiotic relationship between Symbiodiniaceae microalgae and the host breaks down. The endosymbiont communities are known to shift in response to environmental disturbances, but how they respond within and between colonies during and following bleaching events remains unclear. In 2016, a major global-scale bleaching event hit countless tropical reefs. Here, we investigate the relative abundances of Cladocopium LaJeunesse \& H.J.Jeong, 2018 and Durusdinium LaJeunesse, 2018 within and among Pachyseris speciosa colonies in equatorial Singapore that are known to host both these Symbiodiniaceae clades. Bleached and unbleached tissues from bleaching colonies, as well as healthy colonies, during and following the bleaching event were sampled and analyzed for comparison. The nuclear ribosomal internal transcribed spacer (ITS) regions were separately amplified and quantified using a SYBR Green-based quantitative polymerase chain reaction (qPCR) method and Illumina high-throughput sequencing. We found Cladocopium to be highly abundant relative to Durusdinium. The relative abundance of Durusdinium, known to be thermally tolerant, was highest in post-bleaching healthy colonies, while bleached and unbleached tissues from bleaching colonies as well as tissue from healthy colonies during the event had depressed proportions of Durusdinium. Given the importance of Durusdinium for thermal tolerance and stress response, it is surprising that bleached tissue showed limited change over healthy tissue during the bleaching event. Moreover, colonies were invariably dominated by Cladocopium during bleaching, but a minority of colonies were Durusdinium-dominant during non-bleaching times. The detailed characterization of Symbiodiniaceae in specific colonies during stress and recovery will provide insights into this crucial symbiosis, with implications for their responses during major bleaching events.
\end{abstract}

Keywords: coral reef; internal transcribed spacer; Pachyseris speciosa; qPCR; Scleractinia; Southeast Asia; Symbiodiniaceae

\section{Introduction}

Over half of all stony corals (Cnidaria: Anthozoa: Scleractinia) [1,2] live in obligate symbiosis with microscopic dinoflagellates of the family Symbiodiniaceae [3], which ultimately support the existence of shallow-water coral reefs in the world's oceans $[4,5]$. These microalgal endosymbionts provide 
for nearly all of the coral hosts' energetic requirements for growth and production of their calcium carbonate skeleton [6-8]. Therefore, this mutualistic relationship is one of the main foundations of the bioconstruction and functioning of coral reef ecosystems.

Symbiodiniaceae microalgae are extremely diverse, and a single coral can harbor multiple genera and species. There are at least nine recognized genus-level clades (previously known as clade A to clade I) [3], with each clade further divided into genetically diverse subclades or types [9-12]. Critically, the ability of the coral host to tolerate and recover from stress is strongly mediated by the Symbiodiniaceae community present within it, as different clades are known to have varying physiological responses to environmental conditions [13,14]. For instance, Durusdinium LaJeunesse 2018 (formerly clade D) is often found in corals living in regions with large temperature and turbidity fluctuations [3]. Symbiont communities, which may comprise multiple genera but are highly abundant in Durusdinium, could be more resistant to coral bleaching and dissociation from the host [15]. Relatedly, the abundance of Durusdinium relative to Cladocopium LaJeunesse \& H.J.Jeong, 2018 (formerly clade C) is thought to be indicative of stress tolerance, with previous studies showing Durusdinium being dominant in coral colonies that have been affected by temperature fluctuations and bleaching events $[16,17]$. Other symbiotic factors of the coral holobiont, such as bacteria and viruses, are also likely to play a role in mediating coral health during environmental disturbances [18]. Indeed, the dominant Symbiodiniaceae types associated with certain host species during stress can be explained by differential abundances of particular bacterial taxa [19].

The host-symbiont relationship is influenced by many anthropogenically-driven environmental effects, such as ocean acidification, eutrophication and elevated seawater temperatures, that could threaten the health of the coral holobiont [20]. In particular, high temperatures and light levels induce thermal stress and photodamage to the coral holobiont, respectively [21]. A slight increase in temperature can cause the Symbiodiniaceae cells to be expelled from the coral host [22,23], an effect that manifests recognizably as bleaching of the live coral tissue [24]. Prolonged exceedance of seawater temperature by just $1-2{ }^{\circ} \mathrm{C}$ above the maximum monthly mean can result in severe coral bleaching and mortality $[4,25,26]$.

Globally, coral bleaching has been occurring at higher intensities and frequencies since the 1980s [27-29]. From small-scale localized events, coral bleaching is now a regular and widespread phenomenon affecting major reef systems in the Caribbean [30-32], Red Sea [33-35], Indian Ocean [36-39], Indo-West Pacific [40-45], Central Pacific [46-48], Eastern Pacific [49-51] and many more. Most recently, the 2016 global-scale coral bleaching event (GCBE) hit countless tropical reefs, causing widespread damage throughout the world's coastal ecosystems [28,52-54]. For example, coral reefs in Japan were severely affected, with about $40-90 \%$ coral bleaching in the Ryukyu Islands [55,56], and nearly half of all reefs in the Great Barrier Reef experienced severe ( $>60 \%$ of corals) bleaching $[28,29]$. The highly urbanized reefs in Singapore were also not spared, with bleaching recorded for up to $66 \%$ of corals in the intertidal areas and almost $60 \%$ of corals in the subtidal areas [44,57-59].

When bleaching is severe and corals do not recover their endosymbiont communities, a process that may involve the 'shuffling' (change in abundance of preexisting types) or 'switching' (uptake of new environmental types) of dominant and background Symbiodiniaceae types, mortality sets in $[15,31,60,61]$. Because corals' susceptibility to and recovery from bleaching could be strongly influenced by the Symbiodiniaceae taxa present in the host during and after the thermal stress event, a better understanding of the diversity and ecological processes related to the symbiosis is paramount [21,31,62-64].

In this study, we characterize the relative abundances of Cladocopium and Durusdinium among Pachyseris speciosa colonies in Singapore during and after the 2016 major global bleaching event. The coral reef surveys conducted have found P. speciosa to be one of the most common reef corals in the turbid waters here [65-67]. This species was highly susceptible to bleaching during the major event in 2010 [65] and the minor event in 2013 [68], but was found to be less susceptible and better able to recover during the 2016 GCBE [44]. The locally widespread partial-colony bleaching of P. speciosa 
(Figure 1), its high propensity to recover [44] and the known association with both endosymbiont clades [10,69] allow their relative abundances to be studied among colonies of varying bleaching states. Here, we use two distinct methods—quantitative polymerase chain reaction (qPCR [12,17,70-73]) and Illumina high-throughput sequencing (HTS) — targeting the nuclear ribosomal internal transcribed spacers (ITS) [9,74-76] to quantify relative Symbiodiniaceae abundances. Comparing between the bleached and unbleached parts of affected colonies, unbleached colonies and post-bleaching colonies, we aim to test the relative abundances of Durusdinium and Cladocopium in the colonies sampled during and after the mass bleaching event.

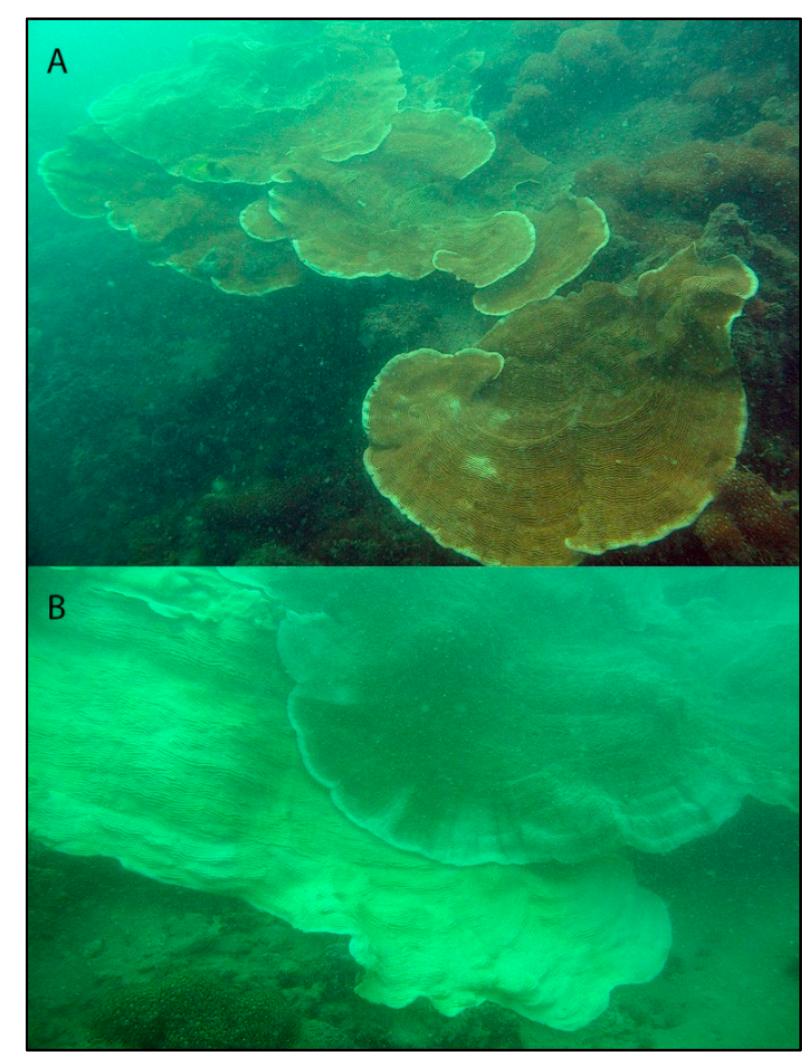

Figure 1. Pachyseris speciosa at Pulau Hantu in June 2016. (A) Healthy colony. (B) Bleached colony showing both bleached and non-bleached tissues.

\section{Materials and Methods}

\subsection{Field Collections}

In total, 39 Pachyseris speciosa colonies were sampled via SCUBA from Pulau Hantu $\left(01^{\circ} 13^{\prime} 36.5^{\prime \prime} \mathrm{N}\right.$ $103^{\circ} 44^{\prime} 47.0^{\prime \prime}$ E), Singapore, during the bleaching event in July 2016. From April to July 2016, local sea surface temperatures exceeded the maximum monthly mean of $29.8^{\circ} \mathrm{C}$ for several weeks, and bleaching threshold of $30.8^{\circ} \mathrm{C}$ for 10 days, with a peak of $31.4^{\circ} \mathrm{C}$ in May 2016 [59]. Fragments of $4-5 \mathrm{~cm}^{2}$ were separately collected from bleached and unbleached portions of each colony undergoing bleaching $(n=19)$, and from a random part of each normal, unbleached colony ( $n=20)$. In 2017 and 2018, 3 and 23 normal, unbleached colonies respectively were sampled as post-bleaching corals. Targeted collection was done in 2018 but we included 2017 samples where available, accounting for the different numbers of samples; the two batches, both from recovered healthy corals, were lumped for analysis where necessary. Samples from 2017 were collected from Pulau Hantu, Raffles Lighthouse $\left(01^{\circ} 09^{\prime} 36.5^{\prime \prime} \mathrm{N}\right.$ $\left.103^{\circ} 44^{\prime} 24.0^{\prime \prime} \mathrm{E}\right)$ and Kusu Island ( $\left.01^{\circ} 13^{\prime} 33.0^{\prime \prime} \mathrm{N} 103^{\circ} 51^{\prime} 34.0^{\prime \prime} \mathrm{E}\right)$, whereas in 2018 they were collected from Pulau Hantu, the site sampled during the 2016 bleaching event. Individual colonies were not tagged and tracked throughout the study, but were randomly collected. All the fragments were 
transported to the laboratory in seawater, immediately fixed in $100 \%$ molecular grade ethanol and stored at $-80^{\circ} \mathrm{C}$ until processing.

\subsection{DNA Extraction}

Total genomic DNA from a $2 \mathrm{~cm}$ piece of tissue was extracted from each sample either with the phenol-chloroform method or DNeasy Blood and Tissue Kit (Qiagen Inc., Hilden, Germany) according to the manufacturer's protocol. For phenol-chloroform extraction, tissue was digested overnight at $55{ }^{\circ} \mathrm{C}$ in $900 \mu \mathrm{L}$ of CTAB (cetyltrimethylammonium bromide) buffer and $20 \mu \mathrm{L}$ of proteinase $\mathrm{K}$ $(20 \mathrm{mg} / \mathrm{mL})$. The digest was treated with phenol-chloroform-isoamyl alcohol (24:25:1) to dissolve lipids and proteins and to isolate the nucleic acids. Precipitated DNA was eluted in $200 \mu \mathrm{L}$ of water and stored at $-80^{\circ} \mathrm{C}$. None of the patterns and results obtained in this study were associated with the two different DNA extraction methods.

\subsection{Quantitative Polymerase Chain Reaction}

The nuclear ribosomal internal transcribed spacer 1 (ITS1) region, located between the $18 \mathrm{~S}$ and $5.8 \mathrm{~S}$ rRNA genes, was targeted for the quantification of relative Cladocopium and Durusdinium rDNA copy numbers. Two samples from the collection were used to generate concentration standards for the ITS1 amplicons of Cladocopium and Durusdinium. The amplicons were quantified using Qubit dsDNA HS Assay Kit (Thermo Fisher Scientific, Waltham, MA, USA) with the Life Technologies Qubit 3.0 Fluorometer (Thermo Fisher Scientific, Waltham, MA, USA) and then diluted to $50 \mathrm{ng} / \mu \mathrm{L}$. For amplification of Cladocopium, the universal forward primer (5'-AAG GAG AAG TCG TAA CAA GGT TTC C $-3^{\prime}$ [70]) and Cladocopium-specific reverse primer (5'-AAG CAT CCC TCA CAG CCA AA-3' [70]) were used. For Durusdinium, the universal forward primer and the Durusdinium-specific reverse primer (5'-CAC CGT AGT GGT TCA CGT GTA ATA G-3' [70]) were used. The amplification profile consisted of an initial denaturation at $95^{\circ} \mathrm{C}$ for $3 \mathrm{~min}$, followed by 40 cycles of $95{ }^{\circ} \mathrm{C}$ for $30 \mathrm{~s}, 53{ }^{\circ} \mathrm{C}$ for $45 \mathrm{~s}, 72{ }^{\circ} \mathrm{C}$ for $45 \mathrm{~s}$ and a 5 min extension step at $72{ }^{\circ} \mathrm{C}$. The size of the PCR products ( 100 bp) was confirmed with gel electrophoresis. The products were then purified using SureClean Plus (Bioline Inc., London, UK) and quantified with the Qubit assay as mentioned above. Amplicon concentration standards were prepared by diluting the purified PCR product to $1 \mathrm{ng} / \mu \mathrm{L}$, and then serially diluting to get 10 standards (1 to $\left.10^{-9} \mathrm{ng} / \mu \mathrm{L}\right)$ each for Cladocopium and Durusdinium. All standards were run alongside each quantitative PCR (qPCR) experiment.

All DNA extracts were quantified and diluted to $1 \mathrm{ng} / \mu \mathrm{L}$. SsoAdvanced SYBR Green Supermix (Bio-Rad, Hercules, CA, USA), the above-mentioned primers [70] and diluted standardized DNA template were used for qPCR using the CFX96 Touch ${ }^{\mathrm{TM}}$ Real-Time PCR Detection System (Bio-Rad, Hercules, CA, USA). All standards and samples were run in triplicates. The thermocycling profile used consists of an initial denaturation at $98^{\circ} \mathrm{C}$ for $3 \mathrm{~min}$ followed by 40 cycles of $95^{\circ} \mathrm{C}$ for $15 \mathrm{~s}$ and $60{ }^{\circ} \mathrm{C}$ for $30 \mathrm{~s}$. A melt curve analysis from $65^{\circ} \mathrm{C}$ to $95^{\circ} \mathrm{C}\left(0.5^{\circ} \mathrm{C}\right.$ increase per $\left.5 \mathrm{~s}\right)$ was subsequently performed to verify the specificity of the amplification.

CFX Manager ${ }^{\mathrm{TM}}$ Software (Bio-Rad, Hercules, CA, USA) was used to analyze the efficiency of standards and to enumerate the relative quantities of Cladocopium and Durusdinium (expressed as log-scaled ratio of Durusdinium concentration to Cladocopium concentration) in each sample based on the standard curve. Previous studies have quantified relative endosymbiont abundances by applying a correction of the ITS copy numbers based on Mieog et al. [17] (see also [70,71]). However, we here explicitly estimated the ratio of Durusdinium to Cladocopium ITS concentrations in the standardized DNA extract, which allowed comparisons among the different coral conditions and also with the relative read abundances from HTS. We note that the ratios would not reflect actual cell numbers [77].

\subsection{Illumina Library Preparation and Sequencing}

The nuclear ribosomal internal transcribed spacer 2 (ITS2) region was targeted for conventional PCR and HTS. All DNA extracts were quantified and diluted to $1 \mathrm{ng} / \mu \mathrm{L}$. Reagent volumes, PCR cycling conditions 
and PCR clean-up protocols followed the 16S Metagenomic Sequencing Library Preparation guide for the Illumina MiSeq System [78]. This two-step protocol included an amplicon PCR (1st step) whereby the ITS2-specific SYM_VAR primer pair (SYM_VAR_5.8S2: 5'-GAATTGCAGAACTCCGTGAACC-3' [79], SYM_VAR_REV: 5'-CGGGTTCWCTTGTYTGACTTCATGC-3' [80]) with overhang adapters was used to generate templates for index PCRs. The index PCR (2nd step) used unique dual indexes (see Supplementary Material) with adapters complementary to the MiSeq flow cell for binding. Indexed PCR products were normalized using the SequalPrep ${ }^{\mathrm{TM}}$ Normalization Plate Kit (Thermo Fisher Scientific, Waltham, MA, USA), pooled and sequenced under the Illumina MiSeq sequencing platform (V3 chemistry) for 300-bp paired-end reads.

Demultiplexed paired fastq.gz files containing Symbiodiniaceae ITS2 reads were analyzed using the SymPortal framework [81], run locally. Briefly, sequence filtering and a standardized quality control pipeline were conducted using mothur 1.39.5 [82], the BLAST+ suite [83] and minimum entropy decomposition (MED [84]). The community matrix output corresponding to the number of sequencing reads in each sample following the SymPortal pipeline was used for downstream Symbiodiniaceae sequence analyses.

\subsection{Statistical Analyses}

Data were analyzed using R 3.6.1 (R Core Team 2017 [85]). The ratios of Durusdinium to Cladocopium ITS1 concentrations obtained from the qPCR experiments were compared among the five groups of Pachyseris speciosa samples-normal (N), normal part of bleached colonies (BN), bleached part of bleached colonies (BB), post-bleaching colonies collected in 2017 (PB2017) and post-bleaching colonies collected in 2018 (PB2018). The ratios of Durusdinium to Cladocopium ITS2 read abundances were also compared among the five groups. As group variances were heterogeneous and sample sizes unequal, we used the Kruskal-Wallis test to detect differences among groups, and the post-hoc Dunn test with the Benjamini-Hochberg (1995) adjustment for multiple comparisons.

To determine if the Symbiodiniaceae communities were distinct among the five groups of Pachyseris speciosa samples, we used the vegan 2.5-6 package [86] to run non-metric multidimensional scaling (NMDS) and analysis of similarities (ANOSIM; 999 permutations), with the Bray-Curtis dissimilarity computed based on ITS2 subclade proportional read abundances. A Venn diagram to visualize shared and unshared subclades among the five treatments was constructed using the venn 1.9 package. To investigate Symbiodiniaceae clade dominance before, during and after the 2016 GCBE, we used a chi-square test to compare frequencies of colonies that were dominated by Durusdinium vs. Cladocopium. The test was conducted among the 15 colonies collected in July 2015 by Smith et al. [69], the 39 colonies collected in July 2016 and the 24 colonies collected in 2017 and 2018, all exclusively from the Pulau Hantu site only.

Finally, to determine if and how the qPCR tests and HTS reads were comparable in the relative Durusdinium vs. Cladocopium levels obtained, we ran a linear model to quantify the relationship between relative (Durusdinium divided by Cladocopium) ITS1 concentrations and ITS2 read abundances at the sample level. Data were log-transformed for normality and homoscedasticity.

\section{Results}

The qPCR quantification of relative concentrations of Durusdinium vs. Cladocopium ITS1 based on 84 coral samples showed significant differences among the five groups of Pachyseris speciosa samples (N, BN, BB, PB2017 and PB2018; Kruskal-Wallis chi-square $=29.8, p<0.001$; Figure 2A). Post-hoc Dunn tests indicated that the post-bleaching colonies in 2018 (PB2018) had the largest Durusdinium proportions, significantly greater than the unbleached (N, $p<0.001)$ and bleached (BN, $p<0.001$; $\mathrm{BB}, p=0.008$ ) colonies in 2016. The bleached part of bleached colonies (BB) had similar proportions of Durusdinium compared to unbleached colonies and tissues (N and BN respectively) during the 2016 GCBE, while the post-bleaching colonies (PB2017 and PB2018) were not significantly different from each other. Overall, relative levels of Durusdinium vs. Cladocopium were more variable in corals 
after the bleaching event (PB2017 and PB2018; Figure 2A), with three colonies in 2018 dominated by Durusdinium, rather than by Cladocopium as was the case for all other colonies.

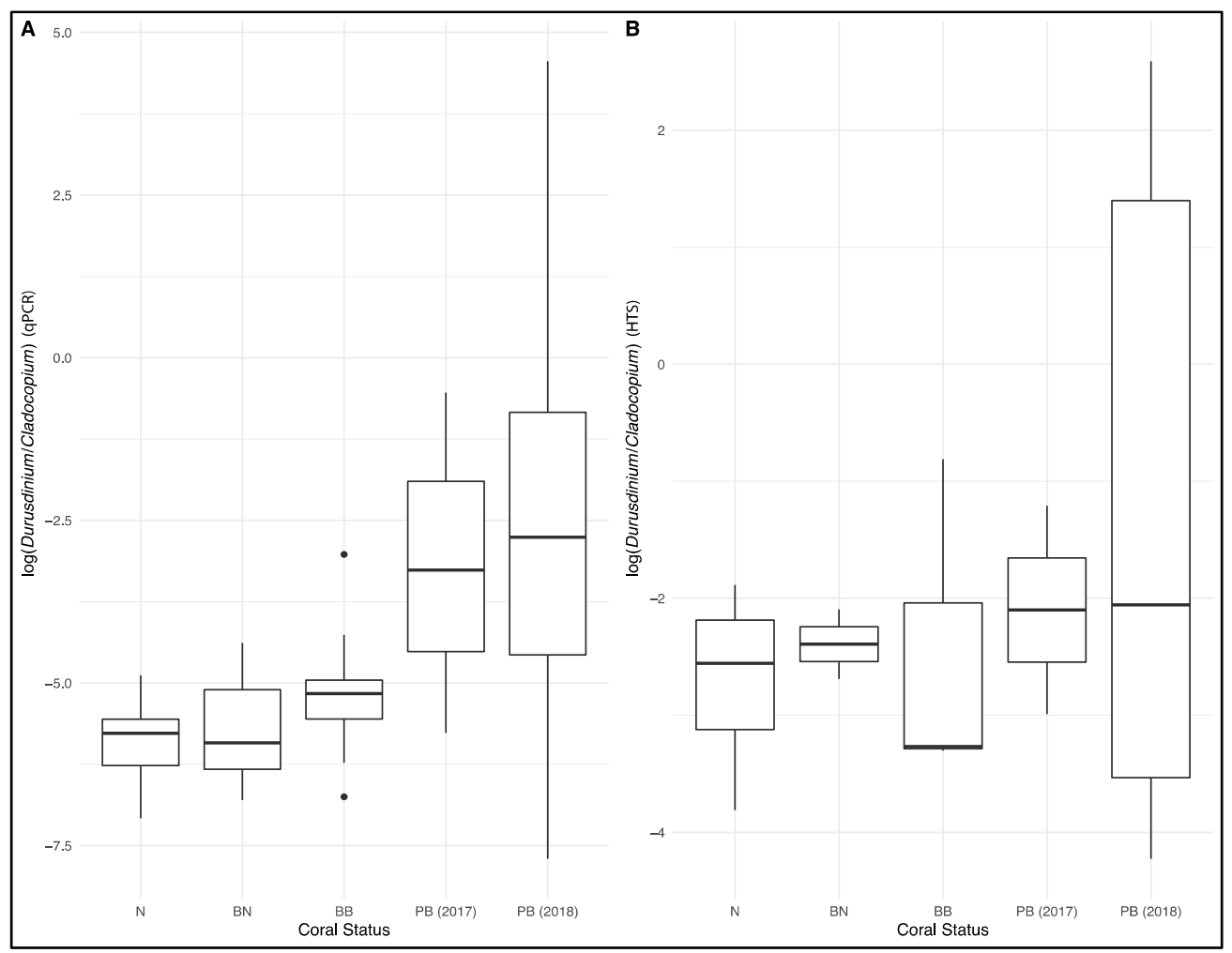

Figure 2. Ratios of Durusdinium to Cladocopium abundance in the five different coral groups (N: normal colonies in 2016, BN: normal portions of the bleached colonies in 2016, BB: bleached portions of the bleached colonies in 2016, PB (2017): post-bleaching colonies in 2017, PB (2018): post-bleaching colonies in 2018). (A) Ratios obtained from quantitative polymerase chain reaction (qPCR). (B) Ratios obtained from high-throughput sequencing (HTS; Illumina).

Illumina sequencing of the 84 coral samples yielded a total of 13,310,311 raw reads, resulting in $9,863,105$ contigs. Following quality control and sequence filtering, a total of 5,250,803 Symbiodiniaceae ITS2 sequences comprising 50,897 unique sequences were retained. Across all colonies, a total of 141 Symbiodiniaceae types, comprising 61 Cladocopium and 80 Durusdinium types, were identified via the SymPortal framework. Symbiodiniaceae C27 was the most abundant type and was found in all coral samples. Symbiodiniaceae D1 was the most abundant Durusdinium type distributed among the normal and post-bleaching colonies, with the highest abundance in the post-bleaching colonies (Figures 3 and 4). On average, each sample contained 9.9 Symbiodiniaceae types. Normal colonies from 2016 had the highest number of unique symbiont types (51), and there were only 12 types shared among all colonies (Figure 5). The richness of Symbiodiniaceae types was lower in the bleaching colonies (64) compared to normal colonies (73) during the 2016 GCBE, and this was further depressed post-bleaching (45).

The relative abundances of Durusdinium vs. Cladocopium ITS2 reads were significantly different among the five groups of P. speciosa samples (N, BN, BB, PB2017 and PB2018; Kruskal-Wallis chi-square $=20.6$, $p<0.001$; Figure 2B). The post-bleaching colonies in 2018 (PB2018) showed greater relative abundances of Durusdinium reads compared to the bleached colonies in 2016 (Dunn test; $\mathrm{BN}, p=0.006$; $\mathrm{BB}, p=0.005$ ). The normal colonies $(\mathrm{N})$ had greater relative abundances of Durusdinium reads compared to both parts of bleached colonies (BN, $p<0.001 ; \mathrm{BB}, p=0.01$ ) during the $2016 \mathrm{GCBE}$, while post-bleaching colonies (PB2017 and PB2018) were not significantly different from each other. Overall, the relative read abundances of Durusdinium vs. Cladocopium were more variable in corals after the bleaching event (PB2017 and PB2018; 
Figure 2B), with six colonies in 2018 dominated by Durusdinium, rather than by Cladocopium as for all other colonies (Figure 4).

The community analysis based on ITS2 proportional read abundances showed that the vast majority of the colonies during and post-GCBE had similar endosymbiont communities, forming a distinct well-populated cluster on the NMDS (Figure 6). In particular, all 20 normal colonies and nearly all of the bleached colonies during the bleaching event showed similar community structures. The six colonies dominated by Durusdinium in 2018 were distinct from the general cluster along the first NMDS axis. Overall, ANOSIM showed that the Symbiodiniaceae communities were distinct among the five groups of coral samples $(R=0.091, p=0.001$ ). Symbiodiniaceae clade dominance (Durusdinium vs. Cladocopium) in 2015, during the 2016 GCBE and in 2017-2018, were significantly differentiated based on the chi-square test for both the qPCR $(p=0.0454)$ and HTS $(p=0.0056)$ datasets.

The overall patterns of relative Durusdinium vs. Cladocopium levels were consistent between the qPCR tests and HTS reads (Figure 2). However, at the sample level, the relationship between relative ITS1 concentrations (qPCR) and ITS2 HTS read abundances was weak $\left(R^{2}=0.116, p=0.00161\right.$; Figure S1). While all samples inferred to be dominated by Cladocopium via HTS were also inferred to be so by qPCR, three colonies from 2018 estimated to have more Durusdinium than Cladocopium by HTS were not validated by the qPCR assay.

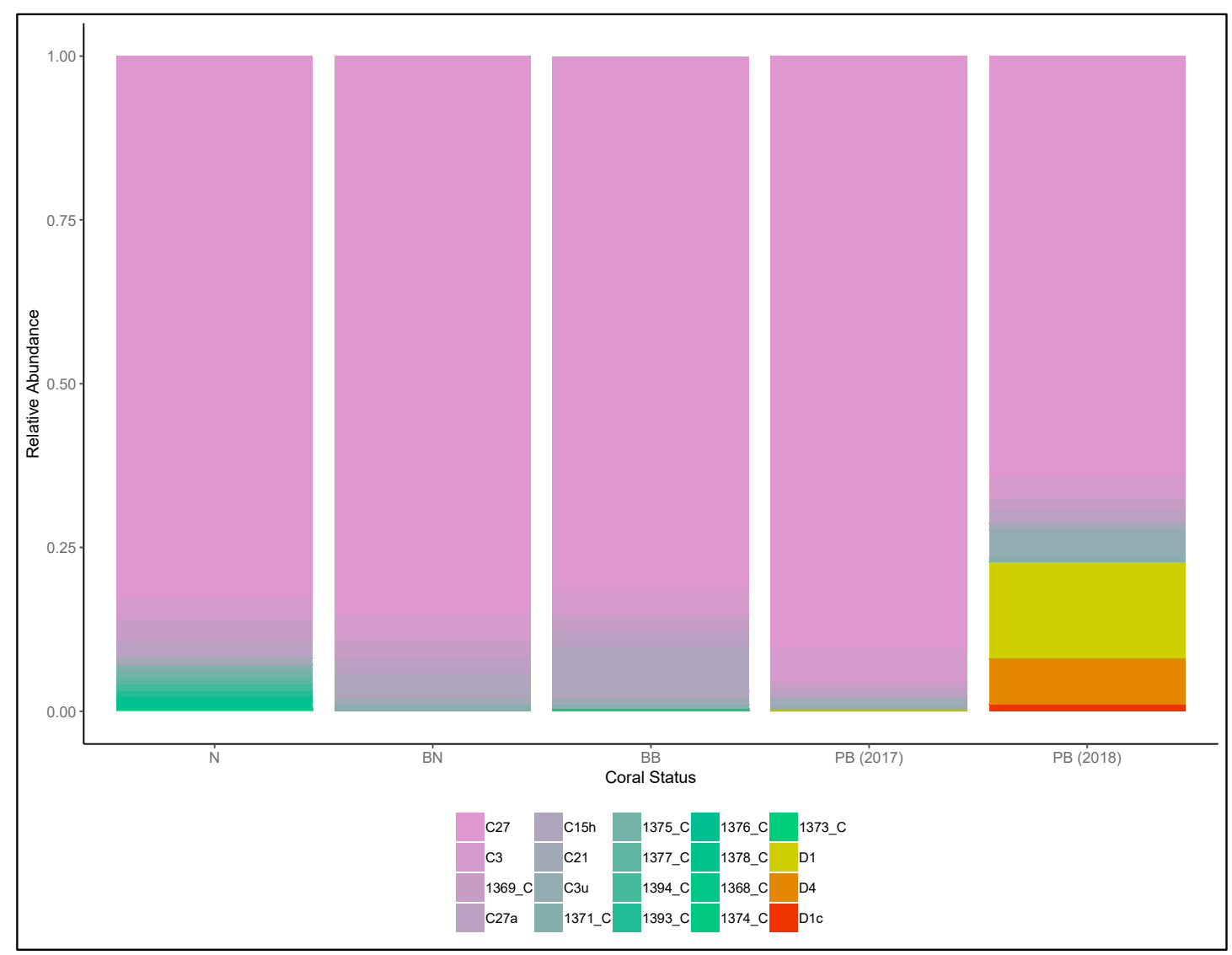

Figure 3. Diversity and relative abundances of Symbiodiniaceae types among the five different coral groups (N: normal colonies in 2016, BN: normal portions of the bleached colonies in 2016, BB: bleached portions of the bleached colonies in 2016, PB (2017): post-bleaching colonies in 2017, PB (2018): post-bleaching colonies in 2018). 


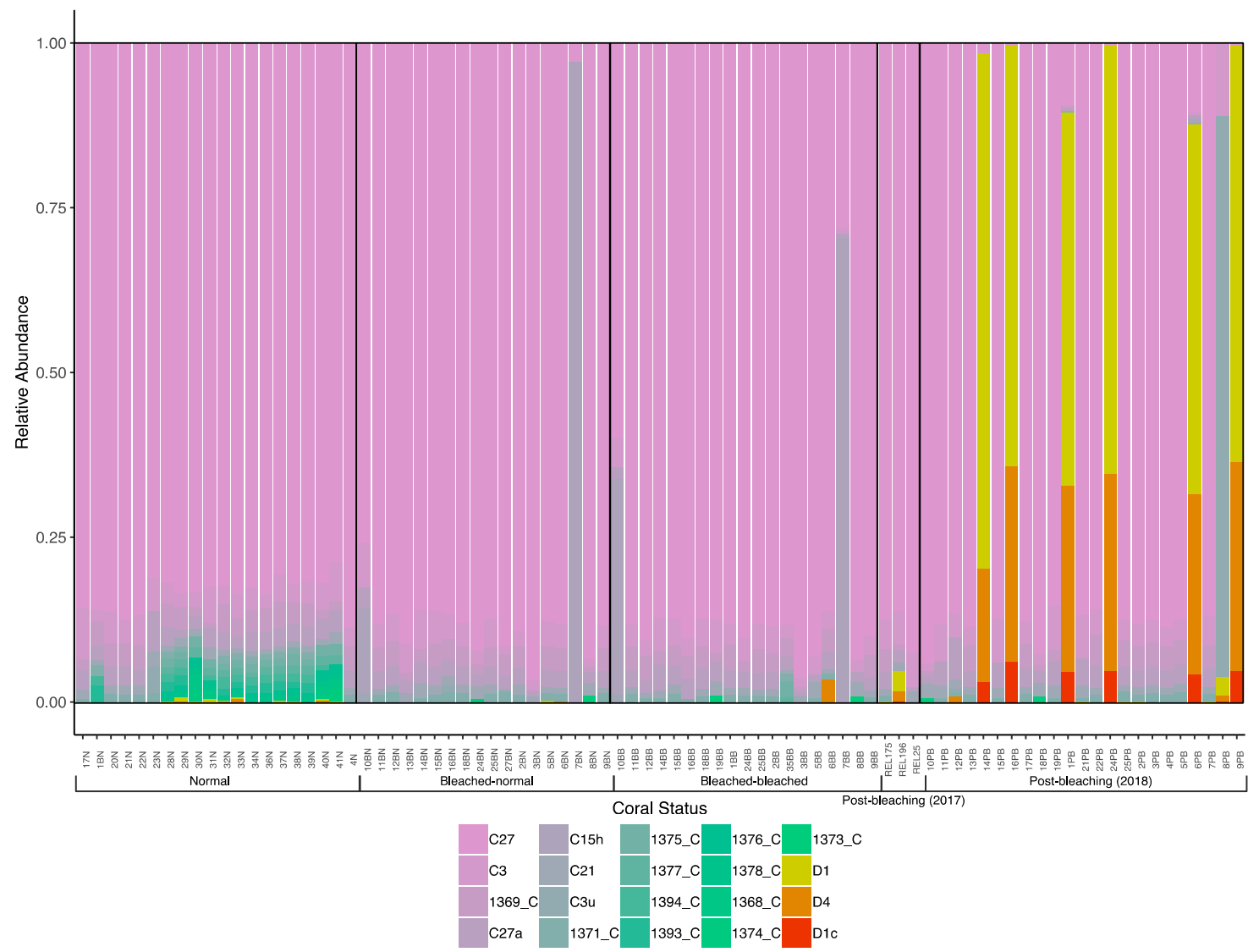

Figure 4. Diversity and relative abundances of Symbiodiniaceae types among all the colonies of Pachyseris speciosa analyzed.

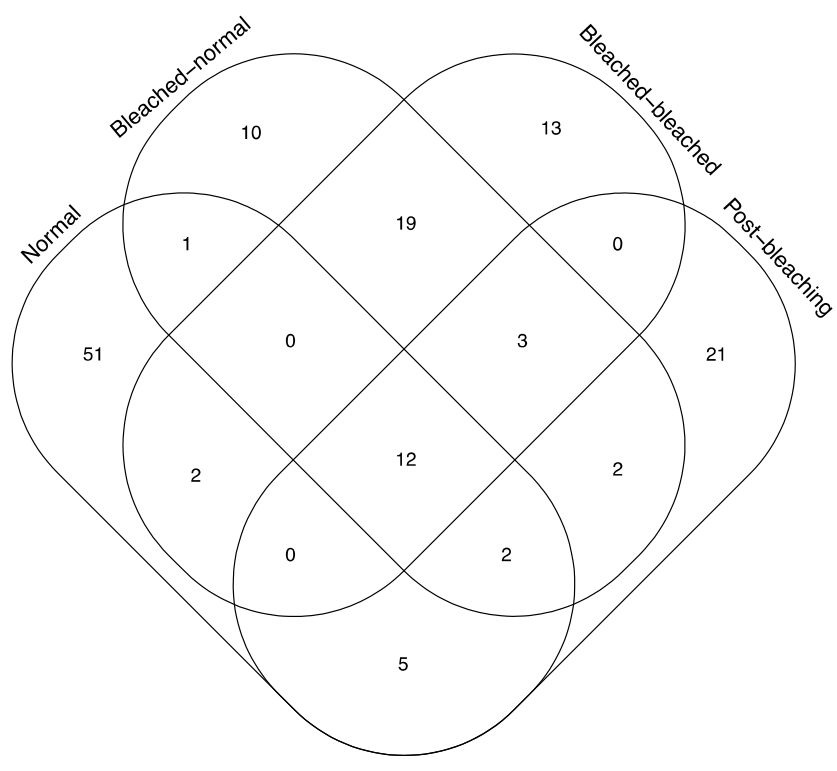

Figure 5. Venn diagram of shared and unique Symbiodiniaceae types among the five different coral groups. Post-bleaching corals include those from 2017 and 2018. 


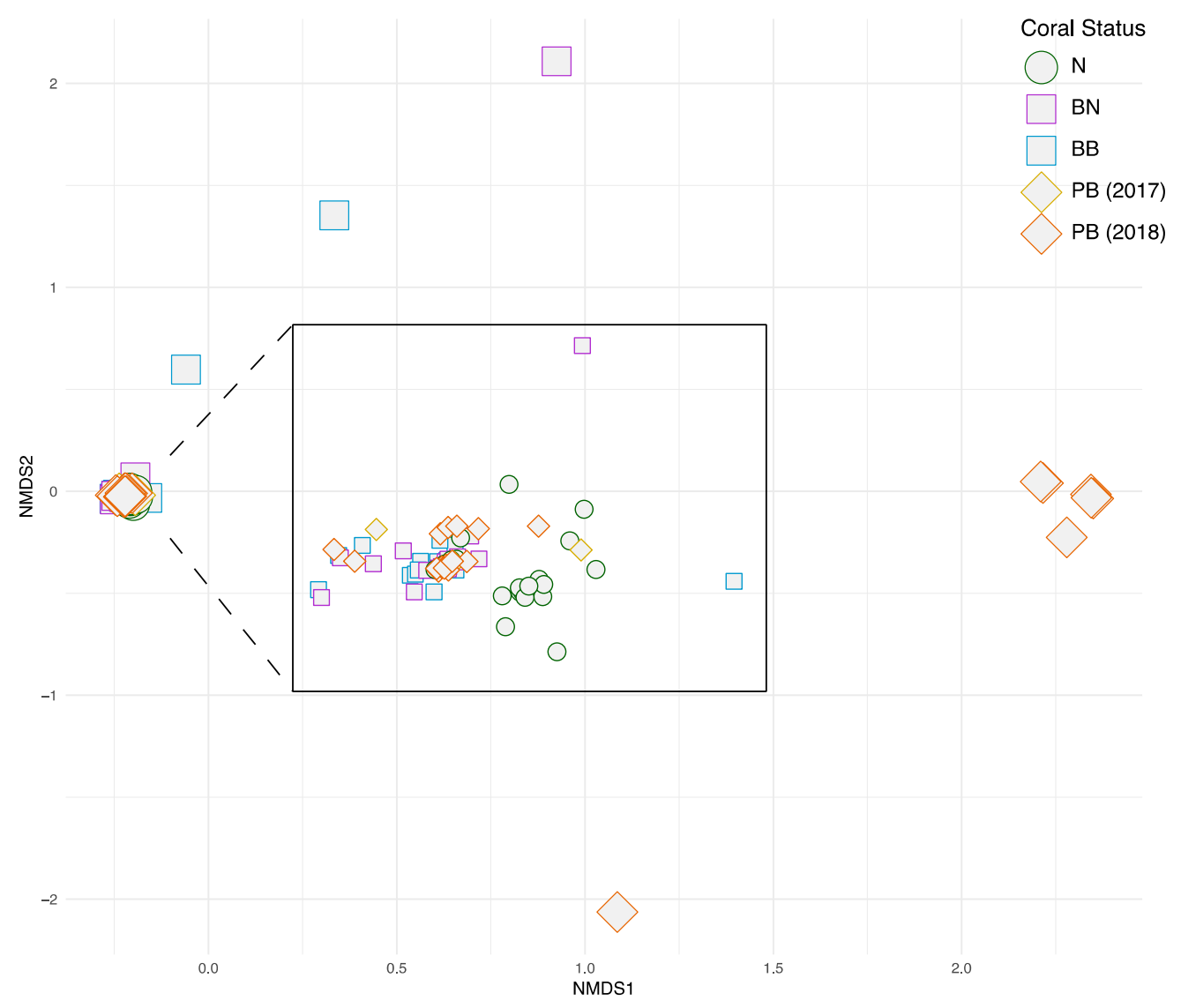

Figure 6. Non-metric multidimensional scaling (NMDS) based on proportional abundances of Symbiodiniaceae types with each point representing a coral sample (N: normal colonies in 2016, BN: normal portions of the bleached colonies in 2016, BB: bleached portions of the bleached colonies in 2016, PB (2017): post-bleaching colonies in 2017, PB (2018): post-bleaching colonies in 2018). Inset shows expanded main cluster.

\section{Discussions}

In this study, the relative abundances of Cladocopium and Durusdinium hosted by the common Pachyseris speciosa coral were compared among colonies collected during and after the 2016 GCBE in Singapore. As expected, Cladocopium was the most abundant Symbiodiniaceae genus in nearly all the colonies examined, though it was less diverse than Durusdinium, with 61 unique ITS2 sequences recovered compared to Durusdinium's 80. These findings corroborate multiple characterizations of P. speciosa, a common and widespread coral species, including those found previously in Singapore across multiple sites [10,69] as well as in Australia [87-89] and Okinawa, Japan [87]. Indeed, Cladocopium is known to be the most abundant Symbiodiniaceae genus in many Indo-Pacific coral reef communities [3].

Based on the Illumina sequencing reads, the SymPortal framework revealed 141 unique Symbiodiniaceae ITS2 types across all colonies collected from 2016 to 2018. Among all types, clade C27 was highly abundant in all the Pachyseris speciosa colonies, with D1 also occurring in all samples and subclade $\mathrm{C} 1$ present in very low abundances in two of the colonies from 2016. On the one hand, a previous study utilizing denaturing gel gradient electrophoresis (DGGE) only found C27 as the dominant type in two of five colonies, whereas C1 and D1 were the primary types in the remaining colonies [10]. It is likely that the distinct type dominance pattern obtained in that study was due to known amplification biases affecting community diversity analyses [90]. On the other hand, Smith et al. [69] showed a dominance of the ITS2 type profile C27/C3/C3u-C115 in Pachyseris speciosa 
colonies in Pulau Hantu collected in 2015, similar to the dominant type profile of C27/C3/C27a found here. Overall, C27 was the most dominant type from 2015, through the 2016 GCBE, to 2018.

Interestingly, Durusdinium, which is associated with resistance to high temperatures and turbidity fluctuations $[15,70,91]$, was found in higher relative abundance in the post-bleaching colonies from 2018. In particular, the dominance of Cladocopium was lost to Durusdinium in up to 6 of the 23 colonies in 2018, and this was also the case in 2015 among 3 of 15 P. speciosa colonies [69]. Because corals were either Cladocopium or Durusdinium with very high proportional abundance $(>75 \%)$ and with no intermediate states, we cannot rule out the possibility that the lack of Durusdinium-dominant colonies during the 2016 GCBE was simply due to their mortality from bleaching. Nevertheless, even small changes in the endosymbiont community are known to be driven by various environment stressors [92,93]. The switching and/or shuffling of hosted Symbiodiniaceae clades to more tolerant and resistant species can increase survivability in adverse conditions $[31,60,61]$. However, the increased relative abundance and dominance of typically "background" Durusdinium during non-bleaching times $[10,69]$ is surprising (but see Huang et al. [45]), since these colonies would be expected to survive during bleaching events before reverting to climax communities with more Cladocopium after they have recovered [94-96]. Our results suggest that this paradigm needs to be tested more rigorously across different coral species and environmental conditions. Indeed, endosymbiont clades hosted by Pocillopora damicornis, another common Indo-Pacific coral, were tracked at the colony level from bleaching through recovery during a 2014 coral bleaching event in Hawai'i, and showed limited variation in their Symbiodiniaceae profile [97].

Differences in endosymbiont community structure among the five groups of samples $(\mathrm{N}, \mathrm{BN}, \mathrm{BB}$, PB2017 and PB2018) support the clade dominance patterns. The communities during the bleaching event were much less variable compared to those hosted by the 2018 colonies (Figure 6). Most of the latter had similar Symbiodiniaceae abundance patterns to samples collected during the 2016 GCBE, but a handful were distinct and dominated by Durusdinium. Evidence from previous studies has been equivocal on the relative levels of variability between stressed and unstressed corals. High temperatures have been shown to drive community differences among colonies [98,99], but they can also result in increased stability [100], as our data here illustrate. These community patterns were accompanied by a decrease in Symbiodiniaceae richness from 14.1 types per normal colony and 9.4 types per bleaching colony during the 2016 bleaching event to just 7.8 types per colony after the event (2017-2018). The contrasting and variable symbiont communities among colonies of the same species may be due to other intrinsic and extrinsic factors, including the hosts' acclimatization capacities and spatial differences in physical conditions, respectively [101,102]. Overall, the patterns observed here underscore the flexibility of the symbiosis often associated with bleaching-susceptible corals [103], yet more research is needed to characterize and explain the basic Symbiodiniaceae richness patterns during bleaching and recovery.

qPCR has been used widely to reliably detect and quantify select taxa of Symbiodiniaceae hosted by corals $[17,70,71,104,105]$. While this approach has been relatively efficient and cost-effective for distinguishing Symbiodiniaceae genera, even in comparison with HTS, our method of clade quantification does not account for copy number variation and actual cell numbers $[77,106]$. To circumvent this limitation, we estimated the ratio of Durusdinium to Cladocopium ITS1 concentrations instead, which allowed comparisons within and among coral colonies.

For the last decade, high-throughput sequencing has been a mainstream technique for characterizing coral endosymbionts $[9,75,107,108]$. Most recently, development of the SymPortal analytical framework specifically for the processing of ITS2 amplicon data obtained from HTS has allowed us to characterize Symbiodiniaceae communities at a much finer resolution by accounting for intragenomic ITS2 diversity $[81,109,110]$. Overall, we found qPCR and HTS to produce consistent patterns of relative Durusdinium and Cladocopium abundances (Figure 2), even though the relationship between relative qPCR-estimated concentrations and HTS read abundances was weak (Figure S1). Some of these discrepancies could be due to differential sequence variabilities and amplification efficiencies between the two loci. However, the inference of clade dominance at the sample level can 
be considerably different, given that three colonies from 2018 found to be Durusdinium-dominant by HTS were Cladocopium-dominant based on qPCR. We thus urge caution when studying clade and type abundances, particularly for small sample sizes, and suggest verifying HTS results with qPCR for more precise abundance estimates [111,112].

While the Symbiodiniaceae community patterns are clear based on the year-on-year characterization before [69], during and after the 2016 GCBE, finer temporal sampling closer to the bleaching period would have enabled clarity regarding the hypotheses of whether the dominant clades were changing gradually or abruptly, and if particular clade-dominant colonies had higher mortality rates. The long-term, frequent and focused monitoring of corals at the colony level [113], incorporating endosymbiont genotyping, would help resolve these questions. Because there are also species-specific effects associated with bleaching, recovery and endosymbiosis in general $[98,114]$, a broad range of species spanning different levels of susceptibility and resilience $[44,115,116]$ needs to be studied. Corals are also associated with a complex array of bacterial communities, and it has recently been shown that the dominant Symbiodiniaceae type is linked to particular bacterial abundances under specific disturbance regimes [19]. Therefore, genotyping the different symbiotic components for an integrated analysis would enhance our understanding of the coral holobiont's response, and enable precise predictions about their trajectories during bleaching events $[19,117]$.

In conclusion, this study finds that Pachyseris speciosa colonies which had recovered from the 2016 GCBE hosted higher relative abundances of Durusdinium compared to colonies during the bleaching period. This pattern was driven by a minority of colonies exhibiting Durusdinium, rather than the Cladocopium dominance and stable Symbiodiniaceae community structure shown in all samples taken during the bleaching event. Together with a previous endosymbiont characterization of P. speciosa at the same site in 2015 [69], our findings demonstrate the homogenization of Symbiodiniaceae communities hosted by corals during the 2016 mass bleaching event. Further research is needed into the effects of bleaching on the coral-endosymbiont community and possible interactions with other factors, such as host genotype and bacterial composition. Overall, this study adds to the growing body of work on coral endosymbiont communities, and also imparts a better understanding of the contribution of various Symbiodiniaceae taxa to the resilience of urbanized reefs off Singapore.

Supplementary Materials: The following are available online at http://www.mdpi.com/2076-2607/8/9/1370/s1, Figure S1: The relationship between ITS1 concentrations (qPCR) and ITS2 read abundances (HTS). Supplementary information: Sequences of unique dual indexes and adapters used for Illumina high-throughput sequencing.

Author Contributions: Conceptualization, S.S.J., J.W.P. and D.H.; methodology, S.S.J. and D.H.; formal analysis, S.S.J. and D.H.; investigation, S.S.J. and D.H.; resources, S.S.J., L.A.-R., B.F., O.L., J.W.P., B.J.W. and D.H.; data curation, S.S.J.; writing-original draft preparation, S.S.J. and D.H.; writing-review and editing, S.S.J., L.A.-R., B.F., O.L., B.J.W. and D.H.; visualization, S.S.J. and D.H.; supervision, D.H.; project administration, D.H. and O.R.; funding acquisition, D.H. and O.R. All authors have read and agreed to the published version of the manuscript.

Funding: This research is supported by the National Research Foundation (NRF), Prime Minister's Office, Singapore under its Marine Science R\&D Programme (MSRDP-P03), and both NRF and the Israel Science Foundation for their 2nd Joint Grant Call (NRF2017NRF-ISF002-2658; Grant Number 2658/17).

Acknowledgments: We thank Allen Chen and Shashank Keshavmurthy for sharing the initial protocol and discussions, Andrew Bauman for providing information on a previous study, as well as members of the Reef Ecology Laboratory for assistance and support.

Conflicts of Interest: The authors declare no conflict of interest.

\section{References}

1. Kitahara, M.V.; Fukami, H.; Benzoni, F.; Huang, D. The New Systematics of Scleractinia: Integrating Molecular and Morphological Evidence. In The Cnidaria, Past, Present and Future; Goffredo, S., Dubinsky, Z., Eds.; Springer International Publishing: Berlin/Heidelberg, Germany, 2016; pp. 41-59. 
2. Cairns, S.D.; Hoeksema, B.W.; Van der Land, J. Appendix: List of extant stony corals. Atoll Res. Bull. 1999, 459, 13-46.

3. LaJeunesse, T.C.; Parkinson, J.E.; Gabrielson, P.W.; Jeong, H.J.; Reimer, J.D.; Voolstra, C.R.; Santos, S.R. Systematic Revision of Symbiodiniaceae Highlights the Antiquity and Diversity of Coral Endosymbionts. Curr. Biol. 2018, 28, 2570-2580. [CrossRef] [PubMed]

4. Glynn, P.W. Coral reef bleaching: Facts, hypotheses and implications. Glob. Chang. Biol. 1996, 2, 495-509. [CrossRef]

5. Brown, B.E. Coral bleaching: Causes and consequences. Coral Reefs 1997, 16, 129-138. [CrossRef]

6. Muscatine, L.; McCloskey, L.R.; Marian, R.E. Estimating the daily contribution of carbon from zooxanthellae to coral animal respiration. Limnol. Oceanogr. 1981, 26, 601-611. [CrossRef]

7. Davies, P.S. The role of zooxanthellae in the nutritional energy requirements of Pocillopora eydouxi. Coral Reefs 1984, 2, 181-186.

8. Stat, M.; Morris, E.; Gates, R.D. Functional diversity in coral-dinoflagellate symbiosis. Proc. Natl. Acad. Sci. USA 2008, 105, 9256-9261. [CrossRef]

9. Arif, C.; Daniels, C.; Bayer, T.; Banguera-Hinestroza, E.; Barbrook, A.; Howe, C.J.; Lajeunesse, T.C.; Voolstra, C.R. Assessing Symbiodinium diversity in scleractinian corals via next-generation sequencing-based genotyping of the ITS2 rDNA region. Mol. Ecol. 2014, 23, 4418-4433. [CrossRef]

10. Tanzil, J.T.I.; Ng, A.P.K.; Tey, Y.Q.; Tan, B.H.Y.; Yun, E.Y.; Huang, D. A Preliminary Characterisation of Symbiodinium Diversity in Some Common Corals From Singapore. Cosmos 2016, 12, 15-27. [CrossRef]

11. Pochon, X.; Gates, R.D. A new Symbiodinium clade (Dinophyceae) from soritid foraminifera in Hawai'i. Mol. Phylogenet. Evol. 2010, 56, 492-497. [CrossRef]

12. Rouzé, H.; Lecellier, G.J.; Saulnier, D.; Planes, S.; Gueguen, Y.; Wirshing, H.H.; Berteaux-Lecellier, V. An updated assessment of symbiodinium spp. that associate with common scleractinian corals from moorea (French Polynesia) reveals high diversity among background symbionts and a novel finding of clade B. PeerJ 2017, 2017, e2856. [CrossRef] [PubMed]

13. Cunning, R.; Baker, A.C. Excess algal symbionts increase the susceptibility of reef corals to bleaching. Nat. Clim. Chang. 2013, 3, 259-262. [CrossRef]

14. Rouzé, H.; Lecellier, G.; Saulnier, D.; Berteaux-Lecellier, V. Symbiodinium clades A and D differentially predispose Acropora cytherea to disease and Vibrio spp. colonization. Ecol. Evol. 2016, 6, 560-572. [CrossRef] [PubMed]

15. Baker, A.C. Flexibility and Specificity in Coral-Algal Symbiosis: Diversity, Ecology, and Biogeography of Symbiodinium. Annu. Rev. Ecol. Evol. Syst. 2003, 34, 661-689. [CrossRef]

16. Fabricius, K.E.; Mieog, J.C.; Colin, P.L.; Idip, D.; Van Oppen, M.J.H. Identity and diversity of coral endosymbionts (zooxanthellae) from three Palauan reefs with contrasting bleaching, temperature and shading histories. Mol. Ecol. 2004, 13, 2445-2458. [CrossRef]

17. Mieog, J.C.; Van Oppen, M.J.H.; Cantin, N.E.; Stam, W.T.; Olsen, J.L. Real-time PCR reveals a high incidence of Symbiodinium clade D at low levels in four scleractinian corals across the Great Barrier Reef: Implications for symbiont shuffling. Coral Reefs 2007, 26, 449-457. [CrossRef]

18. Rosenberg, E.; Koren, O.; Reshef, L.; Efrony, R.; Zilber-Rosenberg, I. The role of microorganisms in coral health, disease and evolution. Nat. Rev. Microbiol. 2007, 5, 355-362. [CrossRef]

19. Claar, D.C.; McDevitt-Irwin, J.M.; Garren, M.; Vega Thurber, R.; Gates, R.D.; Baum, J.K. Increased diversity and concordant shifts in community structure of coral-associated Symbiodiniaceae and bacteria subjected to chronic human disturbance. Mol. Ecol. 2020. [CrossRef]

20. Leggat, W.; Seneca, F.; Wasmund, K.; Ukani, L.; Yellowlees, D.; Ainsworth, T.D. Differential responses of the coral host and their algal symbiont to thermal stress. PLoS ONE 2011, 6, e26687. [CrossRef]

21. Hughes, T.P.; Baird, A.H.; Bellwood, D.R.; Card, M.; Connolly, S.R.; Folke, C.; Grosberg, R.; Hoegh-Guldberg, O.; Jackson, J.B.C.; Kleypas, J.; et al. Climate change, human impacts, and the resilience of coral reefs. Science 2003, 301, 929-933. [CrossRef]

22. Glynn, P.W.; Maté, J.L.; Baker, A.C.; Calderón, M.O. Coral bleaching and mortality in Panama and Ecuador during the 1997-1998 El Niño-Southern Oscillation event: Spatial/temporal patterns and comparisons with the 1982-1983 event. Bull. Mar. Sci. 2001, 69, 79-109. 
23. Berkelmans, R.; Van Oppen, M.J.H. The role of zooxanthellae in the thermal tolerance of corals: A "nugget of hope" for coral reefs in an era of climate change. Proc. R. Soc. B Biol. Sci. 2006, 273, 2305-2312. [CrossRef] [PubMed]

24. Van Oppen, M.J.H.; Lough, J.M. Coral Bleaching: Patterns, Processes, Causes and Consequences, 2nd ed.; Springer International Publishing: Berlin/Heidelberg, Germany, 2018.

25. Gleeson, M.W.; Strong, A.E. Applying MCSST to coral reef bleaching. Adv. Space Res. 1995, 16, 151-154. [CrossRef]

26. Claar, D.C.; Szostek, L.; McDevitt-Irwin, J.M.; Schanze, J.J.; Baum, J.K. Global patterns and impacts of El Niño events on coral reefs: A meta-analysis. PLoS ONE 2018, 13, e0190957. [CrossRef] [PubMed]

27. Glynn, P.W. Extensive 'Bleaching' and Death of Reef Corals on the Pacific Coast of Panamá. Environ. Conserv. 1983, 10, 149-154. [CrossRef]

28. Hughes, T.P.; Barnes, M.L.; Bellwood, D.R.; Cinner, J.E.; Cumming, G.S.; Jackson, J.B.C.; Kleypas, J.; Van De Leemput, I.A.; Lough, J.M.; Morrison, T.H.; et al. Coral reefs in the Anthropocene. Nature 2017, 546, 82-90. [CrossRef]

29. Hughes, T.P.; Kerry, J.T.; Baird, A.H.; Connolly, S.R.; Dietzel, A.; Eakin, C.M.; Heron, S.F.; Hoey, A.S.; Hoogenboom, M.O.; Liu, G.; et al. Global warming transforms coral reef assemblages. Nature 2018, 556, 492-496. [CrossRef]

30. Eakin, C.M.; Morgan, J.A.; Heron, S.F.; Smith, T.B.; Liu, G.; Alvarez-Filip, L.; Baca, B.; Bartels, E.; Bastidas, C.; Bouchon, C.; et al. Caribbean corals in crisis: Record thermal stress, bleaching, and mortality in 2005. PLOS ONE 2010, 5, e13969. [CrossRef]

31. Kemp, D.W.; Hernandez-Pech, X.; Iglesias-Prieto, R.; Fitt, W.K.; Schmidt, G.W. Community dynamics and physiology of Symbiodinium spp. before, during, and after a coral bleaching event. Limnol. Oceanogr. 2014, 59, 788-797. [CrossRef]

32. Levas, S.; Schoepf, V.; Warner, M.E.; Aschaffenburg, M.; Baumann, J.; Grottoli, A.G. Long-term recovery of Caribbean corals from bleaching. J. Exp. Mar. Bio. Ecol. 2018, 506, 124-134. [CrossRef]

33. Monroe, A.A.; Ziegler, M.; Roik, A.; Röthig, T.; Hardenstine, R.S.; Emms, M.A.; Jensen, T.; Voolstra, C.R.; Berumen, M.L. In situ observations of coral bleaching in the central Saudi Arabian Red Sea during the 2015/2016 global coral bleaching event. PLoS ONE 2018, 13, e0195814. [CrossRef] [PubMed]

34. Osman, E.O.; Smith, D.J.; Ziegler, M.; Kürten, B.; Conrad, C.; El-Haddad, K.M.; Voolstra, C.R.; Suggett, D.J. Thermal refugia against coral bleaching throughout the northern Red Sea. Glob. Chang. Biol. 2018, 24, e474-e484. [CrossRef] [PubMed]

35. Cantin, N.E.; Cohen, A.L.; Karnauskas, K.B.; Tarrant, A.M.; McCorkle, D.C. Ocean Warming Slows Coral Growth in the Central Red Sea. Science 2010, 329, 322-355. [CrossRef] [PubMed]

36. Brown, B.E.; Dunne, R.P.; Chansang, H. Coral bleaching relative to elevated seawater temperature in the Andaman sea (Indian ocean) over the last 50 years. Coral Reefs 1996, 15, 151-152. [CrossRef]

37. Spencer, T.; Teleki, K.A.; Bradshaw, C.; Spalding, M.D. Coral bleaching in the Southern Seychelles during the 1997-1998 Indian Ocean warm event. Mar. Pollut. Bull. 2000, 40, 569-586. [CrossRef]

38. Cerutti, J.M.B.; Burt, A.J.; Haupt, P.; Bunbury, N.; Mumby, P.J.; Schaepman-Strub, G. Impacts of the 2014-2017 global bleaching event on a protected remote atoll in the Western Indian Ocean. Coral Reefs 2020, 39, 15-26. [CrossRef]

39. McClanahan, T.R.; Baird, A.H.; Marshall, P.A.; Toscano, M.A. Comparing bleaching and mortality responses of hard corals between southern Kenya and the Great Barrier Reef, Australia. Mar. Pollut. Bull. 2004, 48, 327-335. [CrossRef]

40. Marshall, P.A.; Baird, A.H. Bleaching of corals on the Great Barrier Reef: Differential susceptibilities among taxa. Coral Reefs 2000, 19, 155-163. [CrossRef]

41. Berkelmans, R.; De'ath, G.; Kininmonth, S.; Skirving, W.J. A comparison of the 1998 and 2002 coral bleaching events on the Great Barrier Reef: Spatial correlation, patterns, and predictions. Coral Reefs 2004, 23, 74-83. [CrossRef]

42. Ulstrup, K.E.; Berkelmans, R.; Ralph, P.J.; Van Oppen, M.J.H. Variation in bleaching sensitivity of two coral species across a latitudinal gradient on the Great Barrier Reef: The role of zooxanthellae. Mar. Ecol. Prog. Ser. 2006, 314, 135-148. [CrossRef]

43. Bruno, J.F.; Selig, E.R. Regional decline of coral cover in the Indo-Pacific: Timing, extent, and subregional comparisons. PLoS ONE 2007, 2, e711. [CrossRef] [PubMed] 
44. Ng, C.S.L.; Huang, D.; Toh, K.B.; Sam, S.Q.; Kikuzawa, Y.P.; Toh, T.C.; Taira, D.; Chan, Y.K.S.; Hung, L.Z.T.; Sim, W.T.; et al. Responses of urban reef corals during the 2016 mass bleaching event. Mar. Pollut. Bull. 2020, 154, 111111. [CrossRef] [PubMed]

45. Huang, Y.Y.; Carballo-Bolaños, R.; Kuo, C.Y.; Keshavmurthy, S.; Chen, C.A. Leptoria phrygia in Southern Taiwan shuffles and switches symbionts to resist thermal-induced bleaching. Sci. Rep. 2020, 10, 1-11. [CrossRef] [PubMed]

46. Williams, G.J.; Knapp, I.S.; Maragos, J.E.; Davy, S.K. Modeling patterns of coral bleaching at a remote Central Pacific atoll. Mar. Pollut. Bull. 2010, 60, 1467-1476. [CrossRef]

47. Barkley, H.C.; Cohen, A.L.; Mollica, N.R.; Brainard, R.E.; Rivera, H.E.; DeCarlo, T.M.; Lohmann, G.P.; Drenkard, E.J.; Alpert, A.E.; Young, C.W.; et al. Repeat bleaching of a central Pacific coral reef over the past six decades (1960-2016). Commun. Biol. 2018, 1,1-10. [CrossRef]

48. Cohen, A.L.; Lobel, P.S.; Tomasky, G.L. Coral Bleaching on Johnston Atoll, Central Pacific Ocean. Biol. Bull. 1997, 193, 276-279. [CrossRef]

49. Glynn, P.W. Coral Mortality and Disturbances to Coral Reefs in the Tropical Eastern Pacific. Elsevier Oceanogr. Ser. 1990, 52, 55-126.

50. LaJeunesse, T.C.; Reyes-Bonilla, H.; Warner, M.E. Spring "bleaching" among Pocillopora in the Sea of Cortez, Eastern Pacific. Coral Reefs 2007, 26, 265-270. [CrossRef]

51. Jiménez, C.; Cortés, J.; León, A.; Eleazar, R. Coral Bleaching and Mortality Associated with the 1997-98 El Niño in an Upwelling Environment in the Eastern Pacific (Gulf of Papagayo, Costa Rica). Bull. Mar. Sci. 2001, 69, 151-169.

52. Eakin, C.M.; Sweatman, H.P.A.; Brainard, R.E. The 2014-2017 global-scale coral bleaching event: Insights and impacts. Coral Reefs 2019, 38, 539-545. [CrossRef]

53. McClanahan, T.R.; Darling, E.S.; Maina, J.M.; Muthiga, N.A.; D’agata, S.D.; Jupiter, S.D.; Arthur, R.; Wilson, S.K.; Mangubhai, S.; Nand, Y.; et al. Temperature patterns and mechanisms influencing coral bleaching during the 2016 El Niño. Nat. Clim. Chang. 2019, 9, 845-851. [CrossRef]

54. Devotta, D.; De La Cour, J.; Geiger, E.; Gomez, A.; Heron, S.F.; Liu, G.; Marsh, B.; Skirving, W.J.; Eakin, C.M. Overview of the third global coral bleaching event (2014-2017). In Status of Coral Reefs in East Asian Seas Region: 2018, Ministry of the Environment of Japan and Japan Wildlife Research Center, Tokyo, Japan (2018); Kimura, T., Tun, K., Chou, L.M., Eds.; Ministry of the Environment: Tokyo, Japan, 2018; pp. 3-10.

55. Sakai, K.; Singh, T.; Iguchi, A. Bleaching and post-bleaching mortality of Acropora corals on a heat-susceptible reef in 2016. PeerJ 2019, 2019, e8138. [CrossRef] [PubMed]

56. Kayanne, H.; Suzuki, R.; Liu, G. Bleaching in the Ryukyu Islands in 2016 and associated Degree Heating Week threshold. Galaxea J. Coral Reef Stud. 2017, 19, 17-18. [CrossRef]

57. Siau, M.E. Warmer Seas Causing Mass Coral Bleaching in Singapore Waters. Today Online 2016. Available online: https://www.todayonline.com/singapore/warmer-seas-causing-mass-coral-bleaching-singaporewaters (accessed on 7 September 2020).

58. Tan, A. Warming Seas Cause Longest Coral Bleaching in Singapore. Straits Times 2016. Available online: https://www.straitstimes.com/singapore/environment/warming-seas-cause-longest-coral-bleaching-inspore (accessed on 7 September 2020).

59. Toh, T.C.; Huang, D.; Tun, K.; Chou, L.M. Summary of Coral Bleaching from 2014 to 2017 in Singapore. In Status of Coral Reefs in East Asian Seas Region: 2018, Ministry of the Environment of Japan and Japan Wildlife Research Center, Tokyo, Japan (2018); Kimura, T., Tun, K., Chou, L.M., Eds.; Ministry of the Environment: Tokyo, Japan, 2018; pp. 21-23.

60. Baker, A.C. Symbiont Diversity on Coral Reefs and Its Relationship to Bleaching Resistance and Resilience. Coral Heal. Dis. 2004, 177-194.

61. Sampayo, E.M.; Ridgway, T.; Bongaerts, P.; Hoegh-Guldberg, O. Bleaching susceptibility and mortality of corals are determined by fine-scale differences in symbiont type. Proc. Natl. Acad. Sci. USA 2008, 105, 10444-10449. [CrossRef]

62. Boulotte, N.M.; Dalton, S.J.; Carroll, A.G.; Harrison, P.L.; Putnam, H.M.; Peplow, L.M.; Van Oppen, M.J.H. Exploring the Symbiodinium rare biosphere provides evidence for symbiont switching in reef-building corals. ISME J. 2016, 10, 2693-2701. [CrossRef]

63. Baker, D.M.; Freeman, C.J.; Wong, J.C.Y.; Fogel, M.L.; Knowlton, N. Climate change promotes parasitism in a coral symbiosis. ISME J. 2018, 12, 921-930. [CrossRef] 
64. Cunning, R.; Baker, A.C. Not just who, but how many: The importance of partner abundance in reef coral symbioses. Front. Microbiol. 2014, 5, 400. [CrossRef]

65. Guest, J.R.; Low, J.; Tun, K.; Wilson, B.; Ng, C.; Raingeard, D.; Ulstrup, K.E.; Tanzil, J.T.I.; Todd, P.A.; Toh, T.C.; et al. Coral community response to bleaching on a highly disturbed reef. Sci. Rep. 2016, 6, 1-10. [CrossRef]

66. Wong, J.S.Y.; Chan, Y.K.S.; Ng, C.S.L.; Tun, K.P.P.; Darling, E.S.; Huang, D. Comparing patterns of taxonomic, functional and phylogenetic diversity in reef coral communities. Coral Reefs 2018, 37, 737-750. [CrossRef]

67. Chow, G.S.E.; Chan, Y.K.S.; Jain, S.S.; Huang, D. Light limitation selects for depth generalists in urbanised reef coral communities. Mar. Environ. Res. 2019, 147, 101-112. [CrossRef] [PubMed]

68. Chou, L.M.; Toh, T.C.; Toh, K.B.; Ng, C.S.L.; Cabaitan, P.; Tun, K.; Goh, E.; Afiq-Rosli, L.; Taira, D.; Du, R.C.P.; et al. Differential response of coral assemblages to thermal stress underscores the complexity in predicting bleaching susceptibility. PLoS ONE 2016, 11, e0159755. [CrossRef] [PubMed]

69. Smith, E.G.; Gurskaya, A.; Hume, B.C.C.; Voolstra, C.R.; Todd, P.A.; Bauman, A.G.; Burt, J.A. Low Symbiodiniaceae diversity in a turbid marginal reef environment. Coral Reefs 2020, 39, 545-553. [CrossRef]

70. Ulstrup, K.E.; Van Oppen, M.J.H. Geographic and habitat partitioning of genetically distinct zooxanthellae (Symbiodinium) in Acropora corals on the Great Barrier Reef. Mol. Ecol. 2003, 12, 3477-3484. [CrossRef] [PubMed]

71. Correa, A.M.S.; McDonald, M.D.; Baker, A.C. Development of clade-specific Symbiodinium primers for quantitative PCR (qPCR) and their application to detecting clade D symbionts in Caribbean corals. Mar. Biol. 2009, 156, 2403-2411. [CrossRef]

72. Chen, C.P.; Tseng, C.H.; Chen, C.A.; Tang, S.L. The dynamics of microbial partnerships in the coral Isopora palifera. ISME J. 2011, 5, 728-740. [CrossRef] [PubMed]

73. Keshavmurthy, S.; Hsu, C.M.; Kuo, C.Y.; Meng, P.J.; Wang, J.T.; Chen, C.A. Symbiont communities and host genetic structure of the brain coral Platygyra verweyi, at the outlet of a nuclear power plant and adjacent areas. Mol. Ecol. 2012, 21, 4393-4407. [CrossRef]

74. Smith, E.G.; Ketchum, R.N.; Burt, J.A. Host specificity of Symbiodinium variants revealed by an ITS2 metahaplotype approach. ISME J. 2017, 11, 1500-1503. [CrossRef] [PubMed]

75. Ziegler, M.; Arif, C.; Burt, J.A.; Dobretsov, S.; Roder, C.; LaJeunesse, T.C.; Voolstra, C.R. Biogeography and molecular diversity of coral symbionts in the genus Symbiodinium around the Arabian Peninsula. J. Biogeogr. 2017, 44, 674-686. [CrossRef]

76. Gong, S.; Chai, G.J.; Xiao, Y.; Xu, L.; Yu, K.; Li, J.; Liu, F.; Cheng, H.; Zhang, F.; Liao, B.; et al. Flexible symbiotic associations of Symbiodinium with five typical coral species in tropical and subtropical reef regions of the northern South China Sea. Front. Microbiol. 2018, 9, 2485. [CrossRef]

77. Saad, O.S.; Lin, X.; Ng, T.Y.; Li, L.; Ang, P.; Lin, S. Genome Size, rDNA Copy, and qPCR Assays for Symbiodiniaceae. Front. Microbiol. 2020, 11, 847. [CrossRef] [PubMed]

78. Illumina. 16S Metagenomic Library Preparation. Available online: https:/support.illumina.com/documents/ documentation/chemistry_documentation/16s/16s-metagenomic-library-prep-guide-15044223-b (accessed on 7 September 2020).

79. Hume, B.C.C.; D'Angelo, C.; Smith, E.G.; Stevens, J.R.; Burt, J.; Wiedenmann, J. Symbiodinium thermophilum sp. nov., a thermotolerant symbiotic alga prevalent in corals of the world's hottest sea, the Persian/Arabian Gulf. Sci. Rep. 2015, 5, 1-8. [CrossRef] [PubMed]

80. Hume, B.; D’Angelo, C.; Burt, J.; Baker, A.C.; Riegl, B.; Wiedenmann, J. Corals from the Persian/Arabian Gulf as models for thermotolerant reef-builders: Prevalence of clade C3 Symbiodinium, host fluorescence and ex situ temperature tolerance. Mar. Pollut. Bull. 2013, 72, 313-322. [CrossRef] [PubMed]

81. Hume, B.C.C.; Smith, E.G.; Ziegler, M.; Warrington, H.J.M.; Burt, J.A.; LaJeunesse, T.C.; Wiedenmann, J.; Voolstra, C.R. SymPortal: A novel analytical framework and platform for coral algal symbiont next-generation sequencing ITS2 profiling. Mol. Ecol. Resour. 2019, 19, 1063-1080. [CrossRef] [PubMed]

82. Schloss, P.D.; Westcott, S.L.; Ryabin, T.; Hall, J.R.; Hartmann, M.; Hollister, E.B.; Lesniewski, R.A.; Oakley, B.B.; Parks, D.H.; Robinson, C.J.; et al. Introducing mothur: Open-source, platform-independent, community-supported software for describing and comparing microbial communities. Appl. Environ. Microbiol. 2009, 75, 7537-7541. [CrossRef] [PubMed]

83. Camacho, C.; Coulouris, G.; Avagyan, V.; Ma, N.; Papadopoulos, J.; Bealer, K.; Madden, T.L. BLAST+: Architecture and applications. BMC Bioinform. 2009, 10, 421. [CrossRef] 
84. Eren, A.M.; Morrison, H.G.; Lescault, P.J.; Reveillaud, J.; Vineis, J.H.; Sogin, M.L. Minimum entropy decomposition: Unsupervised oligotyping for sensitive partitioning of high-throughput marker gene sequences. ISME J. 2015, 9, 968-979. [CrossRef]

85. R Core Team. R: A Language and Environment for Statistical Computing; R Foundation for Statistical Computing: Vienna, Austria, 2017.

86. Oksanen, J.; Blanchet, F.G.; Friendly, M.; Kindt, R.; Legendre, P.; Mcglinn, D.; Minchin, P.R.; O’hara, R.B.; Simpson, G.L.; Solymos, P.; et al. Package “vegan”: Community Ecology Package. Community Ecol. Packag. 2019, 2, 1-296.

87. Lajeunesse, T.C.; Bhagooli, R.; Hidaka, M.; deVantier, L.; Done, T.; Schmidt, G.; Fitt, W.; Hoegh-Guldberg, O. Closely related Symbiodinium spp. differ in relative dominance in coral reef host communities across. Mar. Ecol. Ser. 2004, 284, 147-161. [CrossRef]

88. Cooper, T.F.; Ulstrup, K.E.; Dandan, S.S.; Heyward, A.J.; Kühl, M.; Muirhead, A.; O'Leary, R.A.; Ziersen, B.E.F.; van Oppen, M.J.H. Niche specialization of reef-building corals in the mesophotic zone: Metabolic trade-offs between divergent Symbiodinium types. Proc. R. Soc. B Biol. Sci. 2011, 278, 1840-1850. [CrossRef]

89. Bongaerts, P.; Sampayo, E.M.; Bridge, T.C.L.; Ridgway, T.; Vermeulen, F.; Englebert, N.; Webster, J.M.; Hoegh-Guldberg, O. Symbiodinium diversity in mesophotic coral communities on the Great Barrier Reef: A first assessment. Mar. Ecol. Prog. Ser. 2011, 439, 117-126. [CrossRef]

90. Neilson, J.W.; Jordan, F.L.; Maier, R.M. Analysis of artifacts suggests DGGE should not be used for quantitative diversity analysis. J. Microbiol. Methods 2013, 92, 256-263. [CrossRef] [PubMed]

91. Jones, L.; Acolado, P.; Cala, Y.; Cobi Án, D.; Coelho, V.; Hernández, A.; Jones, R.J.; Mallela, J.; Manfrino, C. The Effects of Coral Bleaching in the Northern Caribbean and Western Atlantic. Faculty Authored Books and Books Contributions 2008, 108. Available online: https://scholar.dominican.edu/books/108 (accessed on 7 September 2020).

92. Buddemeier, R.W.; Fautin, D.G. Coral Bleaching as an Adaptive Mechanism. Bioscience 1993, 43, 320-326. [CrossRef]

93. Baker, A.C. Reef corals bleach to survive change. Nature 2001, 411, 765-766. [CrossRef]

94. Knowlton, N.; Rohwer, F. Multispecies Microbial Mutualisms on Coral Reefs: The Host as a Habitat. Am. Nat. 2003, 162, S51-S62. [CrossRef]

95. Cunning, R.; Silverstein, R.N.; Baker, A.C. Investigating the causes and consequences of symbiont shuffling in a multi-partner reef coral symbiosis under environmental change. Proc. R. Soc. B Biol. Sci. 2015, 282, 20141725. [CrossRef]

96. Silverstein, R.N.; Cunning, R.; Baker, A.C. Change in algal symbiont communities after bleaching, not prior heat exposure, increases heat tolerance of reef corals. Glob. Chang. Biol. 2015, 21, 236-249. [CrossRef]

97. Murphy, J.W.; Spies, N.; Richmond, R. Conservation of Symbiodinium spp. clade in the coral Pocillopora damicornis during the 2014 mass-bleaching event. PeerJ Prepr. 2018. [CrossRef]

98. Parker, K.E.; Ward, J.O.; Eggleston, E.M.; Fedorov, E.; Parkinson, J.E.; Dahlgren, C.P.; Cunning, R. Characterization of a thermally tolerant Orbicella faveolata reef in Abaco, The Bahamas. Coral Reefs 2020, 39, 675-685. [CrossRef]

99. Keshavmurthy, S.; Tee, H.S.; Kao, K.W.; Wang, J.T.; Chen, C.A. Specificity trumps flexibility-location-based stable associations between Symbiodiniaceae genera and Platygyra verweyi (Scleractinia; Merulinidae). PeerJ 2020, 2020, e8791. [CrossRef]

100. D'Angelo, C.; Hume, B.C.C.; Burt, J.; Smith, E.G.; Achterberg, E.P.; Wiedenmann, J. Local adaptation constrains the distribution potential of heat-tolerant Symbiodinium from the Persian/Arabian Gulf. ISME J. 2015, 9, 2551-2560. [CrossRef] [PubMed]

101. Gates, R.D.; Eomund, P.J. The physiological mechanisms of acclimatization in tropical reef corals. Am. Zool. 1999, 39, 30-43. [CrossRef]

102. Nakamura, T.; Van Woesik, R. Water-flow rates and passive diffusion partially explain differential survival of corals during the 1998 bleaching event. Mar. Ecol. Prog. Ser. 2001, 212, 301-304. [CrossRef]

103. Putnam, H.M.; Stat, M.; Pochon, X.; Gates, R.D. Endosymbiotic flexibility associates with environmental sensitivity in scleractinian corals. Proc. R. Soc. B Biol. Sci. 2012, 279, 4352-4361. [CrossRef] [PubMed]

104. Yamashita, H.; Suzuki, G.; Hayashibara, T.; Koike, K. Acropora recruits harbor "rare" Symbiodinium in the environmental pool. Coral Reefs 2013, 32, 355-366. [CrossRef] 
105. Meistertzheim, A.L.; Pochon, X.; Wood, S.A.; Ghiglione, J.F.; Hédouin, L. Development of a quantitative PCR-high-resolution melting assay for absolute measurement of coral-Symbiodiniaceae associations and its application to investigating variability at three spatial scales. Mar. Biol. 2019, 166, 13. [CrossRef]

106. Thornhill, D.J.; Lajeunesse, T.C.; Santos, S.R. Measuring rDNA diversity in eukaryotic microbial systems: How intragenomic variation, pseudogenes, and PCR artifacts confound biodiversity estimates. Mol. Ecol. 2007, 16, 5326-5340. [CrossRef]

107. Quigley, K.M.; Davies, S.W.; Kenkel, C.D.; Willis, B.L.; Matz, M.V.; Bay, L.K. Deep-sequencing method for quantifying background abundances of Symbiodinium types: Exploring the rare Symbiodinium biosphere in reef-building corals. PLoS ONE 2014, 9, e94297. [CrossRef]

108. Cunning, R.; Gates, R.D.; Edmunds, P.J. Using high-throughput sequencing of ITS2 to describe Symbiodinium metacommunities in St. John, US Virgin Islands. PeerJ 2017, 2017, e3472. [CrossRef]

109. Terraneo, T.I.; Fusi, M.; Hume, B.C.C.; Arrigoni, R.; Voolstra, C.R.; Benzoni, F.; Forsman, Z.H.; Berumen, M.L. Environmental latitudinal gradients and host-specificity shape Symbiodiniaceae distribution in Red Sea Porites corals. J. Biogeogr. 2019, 46, 2323-2335. [CrossRef]

110. Howells, E.J.; Bauman, A.G.; Vaughan, G.O.; Hume, B.C.C.; Voolstra, C.R.; Burt, J.A. Corals in the hottest reefs in the world exhibit symbiont fidelity not flexibility. Mol. Ecol. 2020, 29, 899-911. [CrossRef] [PubMed]

111. Stokell, J.R.; Hamp, T.J.; Steck, T.R. Examining changes in bacterial abundance in complex communities using next-generation sequencing is enhanced with quantitative PCR. Antonie Leeuwenhoek Int. J. Gen. Mol. Microbiol. 2016, 109, 1161-1166. [CrossRef]

112. Jian, C.; Luukkonen, P.; Yki-Järvinen, H.; Salonen, A.; Korpela, K. Quantitative PCR provides a simple and accessible method for quantitative microbiota profiling. PLOS ONE 2020, 15, e227285. [CrossRef] [PubMed]

113. Obura, D.O.; Aeby, G.; Amornthammarong, N.; Appeltans, W.; Bax, N.; Bishop, J.; Brainard, R.E.; Chan, S.; Fletcher, P.; Gordon, T.A.C.; et al. Coral reef monitoring, reef assessment technologies, and ecosystem-based management. Front. Mar. Sci. 2019, 6, 580. [CrossRef]

114. Fitt, W.K.; Gates, R.D.; Hoegh-Guldberg, O.; Bythell, J.C.; Jatkar, A.; Grottoli, A.G.; Gomez, M.; Fisher, P.; Lajuenesse, T.C.; Pantos, O.; et al. Response of two species of Indo-Pacific corals, Porites cylindrica and Stylophora pistillata, to short-term thermal stress: The host does matter in determining the tolerance of corals to bleaching. J. Exp. Mar. Bio. Ecol. 2009, 373, 102-110. [CrossRef]

115. Loya, Y.; Sakai, K.; Yamazato, K.; Nakano, Y.; Sambali, H.; Van Woesik, R. Coral bleaching: The winners and the losers. Ecol. Lett. 2001, 4, 122-131. [CrossRef]

116. Van Woesik, R.; Sakai, K.; Ganase, A.; Loya, Y. Revisiting the winners and the losers a decade after coral bleaching. Mar. Ecol. Prog. Ser. 2011, 434, 67-76. [CrossRef]

117. Matthews, J.L.; Raina, J.B.; Kahlke, T.; Seymour, J.R.; van Oppen, M.J.H.; Suggett, D.J. Symbiodiniaceae-bacteria interactions: Rethinking metabolite exchange in reef-building corals as multi-partner metabolic networks. Environ. Microbiol. 2020, 22, 1675-1687. [CrossRef]

(C) 2020 by the authors. Licensee MDPI, Basel, Switzerland. This article is an open access article distributed under the terms and conditions of the Creative Commons Attribution (CC BY) license (http://creativecommons.org/licenses/by/4.0/). 